University of Pennsylvania Carey Law School

Penn Law: Legal Scholarship Repository

Faculty Scholarship at Penn Law

10-31-2012

\title{
Antitrust's State Action Doctrine and the Ordinary Powers of Corporations
}

Herbert J. Hovenkamp

University of Pennsylvania Carey Law School

Follow this and additional works at: https://scholarship.law.upenn.edu/faculty_scholarship

Part of the Antitrust and Trade Regulation Commons, Business Organizations Law Commons, Constitutional Law Commons, State and Local Government Law Commons, and the Supreme Court of the United States Commons

\section{Repository Citation}

Hovenkamp, Herbert J., "Antitrust's State Action Doctrine and the Ordinary Powers of Corporations" (2012). Faculty Scholarship at Penn Law. 1904.

https://scholarship.law.upenn.edu/faculty_scholarship/1904

This Article is brought to you for free and open access by Penn Law: Legal Scholarship Repository. It has been accepted for inclusion in Faculty Scholarship at Penn Law by an authorized administrator of Penn Law: Legal Scholarship Repository. For more information, please contact PennlawIR@law.upenn.edu. 


\title{
Antitrust's State Action Doctrine and the Ordinary Powers of Corporations
}

\author{
Herbert Hovenkamp*
}

Corporations chartered under state law have many of the powers of ordinary persons, including the powers to make contracts, to own property, to buy and sell, to enter into joint ventures, supplier or distribution agreements. Municipal corporations and other governmental subdivisions may be granted a similar array of powers. Not only do most corporations have these powers in common with natural persons, but just as natural persons they also operate under the constraint that they may not use them unlawfully. For example, a biological person's "natural" power to enter a contract ${ }^{1}$ does not confer the power to enter a contract in restraint of trade that would be prohibited by section 1 of the Sherman Act. $^{2}$ A corporation has this power only if it is explicitly granted. But by the same token, one should never infer from the mere fact that a corporation was authorized to enter into contracts that it was authorized to engage in price fixing or anticompetitive boycotts.

At the same time, antitrust law's "state action" doctrine permits the states to regulate and even to "authorize" anticompetitive conduct, provided that they state their intention to do so clearly ${ }^{3}$ and that they also actively supervise any private conduct that

\footnotetext{
* Ben V. \& Dorothy Willie Professor of Law, University of Iowa.

${ }^{1}$ In fact, federal statutes convey to at least some natural persons the right to make contracts or transact in property. See 42 U.S.C. $\$ 1981$ ("All persons within the jurisdiction of the United States shall have the same right ...to make and enforce contracts ... as is enjoyed by white persons...."); 42 U.S.C. $\$ 1982$ (similar: "same right ... as is enjoyed by white citizens ... to inherit, purchase, lease, sell, hold, and convey real and personal property").

215 U.S.C. $\$ 1$.

${ }^{3}$ California Retail Liquor Dealers Assn. v. Midcal Alum., 445 U.S. 97, 105 (1980) (the challenged restraint must be "one clearly articulated and affirmatively expressed as state policy”), interpreting Parker v. Brown, 317 U.S. 341 (1943). Cf. Community Communications Co. v. City of Boulder, 455 U.S. 40, 52 (1982) (refusing to infer "clear articulation" from a generalized "home rule" provision that gave municipality power to regulate within its boundaries); Southern Motor Carriers Rate Conf., Inc. v. United States, 471 U.S. 48, 62-63
} 
results from the regulatory scheme. Most courts understand that stating this authorization clearly means that the legislature must have contemplated approval of an action that would otherwise violate the antitrust laws and decided to authorize it anyway. As the Supreme Court has indicated, one uses an objective test and considers whether the challenged conduct was a "foreseeable" consequence of the legislation for which authorization is claimed. ${ }^{4}$ Thus, for example, if an agency that was properly authorized under state law reviewed and approved a merger, then federal courts may be required to stand aside. ${ }^{5}$

A few courts have carried the idea of "authorization" much further, however, concluding that authorizing a firm to engage in its ordinary corporate activities, such as contracting or acquiring assets, also operates to authorize conduct that would otherwise be unlawful under the antitrust laws. This reasoning is incorrect for a number of reasons. First, the states' own antitrust laws almost invariably make clear that by authorizing firms to "contract" or "acquire," they did not mean to authorize anticompetitive acquisitions. ${ }^{6}$ Second, inferring a state action immunity from ordinary corporate powers creates a virtual blanket antitrust exemption for most of the activities engaged in by most American business corporations. For example, virtually all business corporations are "authorized" by corporate law to make contracts, to own property, or to acquire assets, including the assets or equity of other corporations. Collectively this group of powers runs across the full range of potential antitrust violations, from price-fixing agreements to tying and exclusive dealing, boycott agreements, mergers, and most instances of anticompetitive exclusion. Indeed, it

(1985) (authorization for agencies to engage in rate making did not of itself authorize collective rate making).

${ }^{4}$ City of Columbia \& Columbia Outdoor Advertising v. Omni Outdoor Advertising, Inc., 499 U.S. 365, 372-373 (1991); Town of Hallie v. City of Eau Claire, 471 U.S. 34, 42 (1985). See 1 Phillip E. Areeda \& Herbert Hovenkamp, Antitrust Law IIII222-227 (3d ed. 2007).

${ }^{5}$ E.g., FTC v. Equitable Resources, Inc., 512 F.Supp.2d 361 (W.D.Pa. 2007) (finding both clear state articulation of intent to place control of gas mergers under state public utility board, and active supervision of the result).

${ }^{6}$ See 14 Herbert Hovenkamp, Antitrust Law I[2415 (3d ed. 2012) (in press). 
would overrule a great many Supreme Court decisions in which the challenged conduct was lawful as a matter of state corporate law. ${ }^{7}$

"Authorization" in the context of antitrust's state action immunity has two meanings; the first is state authority to do the act. The second is state intent to permit the relevant actor to act anticompetitively, and thus to displace the antitrust laws. A statute giving a quasi-government entity the power to "execute contracts" covers only the first category. Surely no state court would conclude that a simple authorization of state corporations to enter into contracts justified contracting that involved unlawful race discrimination, fraud, or embezzlement, or even state law antitrust violations.

In its en banc Hammond decision the Fifth Circuit recognized these different meanings of authorization, concluding that the Louisiana legislature did not make sufficiently clear its intent to insulate hospitals acting under its authority from antitrust liability. ${ }^{8}$ The defendant, a dominant surgical hospital, pressured health plans and others to give it exclusive rights, thus injuring the plaintiff's development of its rival acute care facility. The district court had granted a motion to dismiss, inferring the power to enter exclusive contracts from the statutory power to contract and enter joint ventures. That statute provided:

${ }^{7}$ E.g., Amerian Needle, Inc. v. NFL, 130 S.Ct. 2201 (2010) (collusion involving incorporated football teams and incorporated NFL property owner); Aspen Skiing Co. v. Aspen Highlands Skiing corp., 472 U.S. 585 (1985) (monopolization against incorporated dominant firm).

${ }^{8}$ Surgical Care Center of Hammond v. Hospital Serv. Dist., 171 F.3d 231 (5th Cir.), cert. denied, 528 U.S. 964 (1999). Subsequently, the Fifth Circuit affirmed a finding that the antitrust laws had not been violated. See 309 F.3d 836 (5th Cir. 2002). See also Shames v. California Travel and Tourism Com'n, 626 F.3d 1079 ( $9^{\text {th }}$ Cir. 2010) (authorization to rental car companies to "pass on" certain fees to customers did not imply authorization for their collusive agreement about how much was to be passed on); First Am. Title Co. v. DeVaugh, 480 F.3d 438 (6th Cir. 2007) (state action immunity did not shield county registries of deeds from claim that they monopolized the market for land title documents by conditioning copying on purchaser's promise not to sell certified copies to third parties, which made it hard for third-party title plants to maintain duplicate land records; state statutes in question gave the registries the power to make contracts, and a limited monopoly to the extent that they received transaction information from the original parties to a land transaction, recorded it, and retained possession of official title documents; but there was no authorization for a restraint on resale of copies of such documents); Capital City Cab Service, Inc. v. Susquehanna Area Reg. Airport Authority, 470 F. Supp. 2d 462 (M.D. Pa. 2006) (mere power to contract not sufficient authorization for allegedly anticompetitive exclusive contract). 
In addition to the powers and duties otherwise provided and notwithstanding any other law to the contrary, the board of commissioners of a hospital service district and any corporation or health facility owned or operated by such district or commission may contract with or engage in a joint venture with any person, corporation, partnership, or group of persons to offer, provide, promote, establish, or sell any hospital health service. ${ }^{9}$

This conclusion was not undermined by the fact that the state statutes authorized "any person, corporation, partnership, or group of persons," to "sell any hospital health service" and that this power was granted "notwithstanding any other law to the contrary." 10 The court refused to conclude from this last statement that "any other law" included the Sherman Act-that is, that the legislature by this ambiguous provision had "clearly articulated" a policy of permitting non-sovereign actors to engage in anticompetitive conduct. ${ }^{11}$ The court then concluded that it would not infer:

a policy to displace competition from naked grants of authority. These are the enabling statutes by which myriad instruments of local government across the country gain basic corporate powers. To infer a policy to displace competition from, for example, authority to enter into joint ventures or other business forms would stand federalism on its head. A state would henceforth be required to disclaim affirmatively antitrust immunity, at the peril of creating an instrument of local government with power the state did not intend to grant. The immediate practical effect would be the extension of the Parker principle downward, contrary to the teaching that local instruments of government are subject to the Sherman Act. ${ }^{12}$

\footnotetext{
${ }^{9}$ LSA-R.S. 46:1077 (emphasis added).

${ }^{10}$ Ibid.

${ }^{11}$ Ibid. Accord Lancaster Community Hospital v. Antelope Valley Hospital District, 940 F.2d 397, 403 (9th Cir. 1991), cert. denied, 502 U.S. 1094 (1992) (“"“when there are abundant indications that a state's policy is to support competition, a subordinate state entity must do more than merely produce an authorization to 'do business' to show that the state's policy is to displace competition." ).

${ }^{12}$ Hammond, 171 F.3d at 236.
} 
Other decisions have too quickly inferred a state policy of permitting anticompetitive conduct from a highly general grant of corporate power. For example, one court granted immunity to an exclusive contract between a municipal hospital and an anesthesiology group because the authorizing statute gave the hospital Board "full, absolute and complete" authority to manage its business affairs, including "the execution of all contracts." ${ }^{13}$ Giving an agency the power to make its own contracts hardly contemplates authorization for the agency to make anticompetitive contracts. ${ }^{14}$

Of course, in many of these cases there was very likely no antitrust violation in the first place. But using the state action doctrine as a way to dispose of weak antitrust claims is bad for two reasons. First, it fails to distinguish competitive from anticompetitive conduct and thus fails to engage the state's true policy with respect to competition. Second, once a particular provision has been found to authorize a particular instance of conduct that same provision may be used in future cases to infer authorization of conduct that is more competitively harmful. For example, once a court has held that the power to make contracts immunizes a hospital's harmless exclusive dealing agreement ${ }^{15}$ it may be hard pressed to explain why the same very general statute does not authorize naked horizontal price fixing. Undoubtedly, many decisions inferring a broad immunity from general corporate powers are driven by the belief that

${ }^{13}$ Scara v. Bradley Memorial Hosp., 1993-2 Trade Cas. I70,353 (E.D. Tenn.). See also Martin v. Memorial Hospital at Gulfport, 86 F.3d 1391 (5th Cir. 1996) (municipal hospital's exclusive contract with physician to supervise kidney disease center was foreseeable consequence of state statute authorizing such hospitals to contract for the provision of services, including entering management contracts, but not explicitly stating that such contracts could be exclusive); Jackson, Tennessee Hospital Co., LLC v. West Tennessee Healthcare, Inc., 2004-1 Trade Cas. 9774,344, 2004 WL 547215 (Feb. 27, 2004) (authority to enter into contracts with physicians implied authority to enter into anticompetitive agreements).

${ }^{14}$ See Jefferson Parish Hosp. Dist. No. 2 v. Hyde, 466 U.S. 2 (1984).

${ }^{15}$ E.g., Martin v. Memorial Hospital at Gulfport, 86 F.3d 1391 (5th Cir. 1996) (municipal hospital's exclusive contract with physician to supervise kidney disease center was foreseeable consequence of state statute authorizing such hospitals to contract for the provision of services, including entering management contracts, but not explicitly stating that such contracts could be exclusive); 
no antitrust violation has occurred. But in that case the proper solution is dismissal on the antitrust merits.

Also incorrect are cases concluding that the power to acquire intellectual property rights implies the power to commit patent misuse or antitrust violations based on abuse of intellectual property rights. For example, one decision held that a statute authorizing a university to acquire and manage assets, including intellectual property, implicitly authorized the university to acquire an exclusive patent license by fraud. ${ }^{16}$ Once again, there may have been no antitrust violation, but lack of violation does not yield state action immunity. Others have inferred an antitrust immunity for anticompetitive exclusive contracts from a broad grant of the power to contract. ${ }^{17}$ On situations in the last class, the power to contract certainly implies the power to enter into at least some exclusive provider agreements, for the great majority of such agreements are lawful. But one would not assume without additional clarification that such authority included the power to enter into the occasionally unlawful, anticompetitive agreement. In sum, the corporation relying on the ordinary corporate grant of the power to contract faces the same set of antitrust risks as any contractor - namely, a duty to avoid the occasional anticompetitive contract.

Equally problematic are decisions holding or suggesting that the power to buy and sell property implies the power to enter into otherwise unlawful mergers. ${ }^{18}$ Nearly all state chartered business corporations have the power to buy and sell property, including corporate equities or assets. Nevertheless, the Clayton Act expressly forbids any "person" from merging unlawfully, and makes clear that "person" includes

${ }^{16}$ Recombinant DNA Technology \& Patent Contract Litigation, 874 F. Supp. 904 (S.D. Ind. 1994). The statute authorized the university to "acquire by grant, purchase, gift, devise, lease, or by the exercise of the right of eminent domain, and ... hold, use, sell, lease, or dispose of any real or personal property necessary for the full exercise or convenient or useful for the carrying on of any of its powers...."

${ }^{17}$ Cf. Willis-Knighton Medical Center v. City of Bossier City, 2 F. Supp. 2d 842 (W.D. La. 1997), rev'd, 178 F.3d 1290 (5th Cir.), cert. dismissed, 527 U.S. 1065 (1999) (district court concludes that state statute authorizing municipal hospitals to make contracts with providers and develop their own strategic plans contemplated that hospital would enter exclusive arrangements with physician providers; Fifth Circuit reverses without opinion).

${ }^{18}$ FTC v. Hospital Bd. of Directors of Lee Cty., 38 F.3d 1184 (11th Cir. 1994) (public hospital's acquisition immune; statute authorizing Board to create a hospital and acquire additional assets as needed appeared to contemplate acquisition of a second hospital). 
corporations. ${ }^{19}$ Already in its very first merger decision on the merits, the Northern Securities case, the Supreme Court held that the fact that the challenged acquisition had been authorized by a state corporation law the permitted one firm to acquire another did not serve to immunize the acquisition from antitrust attack. ${ }^{20}$

In Phoebe Putney the Eleventh Circuit held that the state action doctrine foreclosed an FTC challenge to a hospital merger that was alleged to be anticompetitive. ${ }^{21}$ The Supreme Court has agreed to review the decision.

The authorizing provision that the court found decisive in Phoebe Putney provided that:

Every hospital authority shall be deemed to exercise public and essential governmental functions and shall have all the powers necessary or convenient to carry out and effectuate the purposes and provisions of this article, including, but without limiting the generality of the foregoing, the following powers:

(1) To sue and be sued;

(2) To have a seal and alter the same;

(3) To make and execute contracts and other instruments necessary to exercise the powers of the authority;

\footnotetext{
${ }^{19}$ See 15 U.S.C. $\$ \$ 12,18$.

${ }^{20}$ Northern Securities Co. v. United States, 193 U.S. 197, 345-346 (1904).

${ }^{21}$ F.T.C. v. Phoebe Putney Health Sys., Inc. 663 F.3d 1369 (Dec. 2011), cert. granted, 2012 WL 985316, 80 USLW 3564 (June 25, 2012). The state of Georgia also opposed the merger. See Brief of State of Georgia in further Support of Motion for Preliminary Injunction, $2011 \mathrm{WL}$ 3920707 (M.D.Ga. June 14, 2011). Cf. Palmyra Park Hosp., Inc. v. Phoebe Putney Memorial Hosp., 604 F.3d 1291 ( $11^{\text {th }}$ Cir. 2010) (permitting tying claim against hospital but not hospital authority because claim against latter had been abandoned).
} 
(4) To acquire by purchase, lease, or otherwise and to operate projects; $\ldots .{ }^{22}$

The provision said nothing about anticompetitive mergers that might violate federal antitrust laws. Further, the powers that the statute authorized were powers typically held by any business corporation and many governmental subdivisions. While the hospital authority was for at least some purposes treated as a government subdivision, the Supreme Court has made clear that only the federal government and the "state itself" have sovereignty; as a result, subdivisions must be authorized. ${ }^{23}$ Other subdivisions, including municipalities, have only those powers that the state authorizes for them.

In finding immunity the court reasoned:

...the Georgia legislature must have anticipated anticompetitive harm when it authorized hospital acquisitions by the authorities. It defies imagination to suppose the legislature could have believed that every geographic market in Georgia was so replete with hospitals that authorizing acquisitions by the authorities could have no serious anticompetitive consequences. The legislature could hardly have thought that Georgia's more rural markets could support so many hospitals that acquisitions by an authority would not harm competition. We therefore conclude that, through the Hospital Authorities Law, the Georgia legislature clearly articulated a policy authorizing the displacement of competition. $^{24}$

The court appeared to assume that by stating no exceptions the statute meant to authorize all mergers without regard for federal antitrust law. A more logical reading is that the statute gave the hospital districts the power to make acquisitions, provided that these acquisitions were not unlawful on other grounds. For example, the Georgia Business Corporation Code, just as other state corporation statutes, grants state

${ }^{22}$ O.C.G.A., $\$ 31-7-70,75$.

${ }^{23}$ Community Communications Co. v. City of Boulder, 455 U.S. 40, 52 (1982) (municipality; general grant of regulatory authority to municipality did not contemplate anticompetitive action).

${ }^{24} 663$ F.3d at 1377. 
corporations the right to acquire the stock or assets of other corporations. ${ }^{25}$ The same statute authorizes Georgia corporations to own and convey real property ${ }^{26}$ and to enter contracts. ${ }^{27}$ None of these authorizations is accompanied by an express limitation that these acts may be performed only when they are consistent with antitrust law, criminal law, or any other body of law. Nevertheless, those limitations are uniformly read in by implication, and would not create an immunity for either anticompetitive mergers or price fixing. Thus it hardly seems the case that a "foreseeable result" of the power to make an acquisition is a power to make an anticompetitive acquisition. ${ }^{28}$

The court relied on its previous Lee County decision, which had also rejected an FTC merger challenge on state action grounds. ${ }^{29}$ In that case when state had passed the authorizing statute in question, one of its purposes was to authorize a hospital board to acquire the "only hospital then in existence in Lee County..., giving it $100 \%$ of the market share at that time. ${ }^{30}$ From this the Phoebe Putney court concluded that the legislature must have contemplated that the statute would authorize mergers to monopoly.

What the court failed to see, however, was that the initial acquisition in the Lee County case was not a merger to monopoly at all. The hospital in that case had a $100 \%$ share to begin with, and the statute did no more than facilitate the transfer of this hospital from its previous owners to the new hospital authority. ${ }^{31}$ Transferring a

${ }^{25}$ O.C.G.A., Tit. 14, §14-2-1102; see also id. at $§ 14-2-1105$ (governing plans of merger or share exchange).

${ }^{26} \mathrm{Id} ., \S 14-5-7$.

${ }^{27}$ Id., $\$ 14-3-845$.

${ }^{28}$ The Georgia Code also provides that "The immunity from antitrust liability afforded to local governments by the provisions of Code Sections 36-65-1 and 36-65-2 shall not apply to public providers in the offering and providing of services as defined in this chapter; and public providers shall be subject to applicable antitrust liabilities...."

${ }^{29}$ FTC v. Hospital Bd. Of Directors of Lee County, 38 F.3d 1184 (11 ${ }^{\text {th }}$ Cir. 1994).

${ }^{30}$ Id. at 1186.

${ }^{31}$ See Lee County, 38 F.3d at 1192:

In 1963, when the Board was originally created, there was only one hospital in existence in Lee County. Pursuant to the powers given it, the Board acquired the hospital, creating a monopoly. In 1987, the legislature, with the knowledge that it had given the Board the power to create a monopoly 
hospital with a $100 \%$ market share from one owner to another does not "create" a monopoly but merely reassigns its ownership. By contrast, subsequent acquisitions after multiple hospitals existed in the area would lessen competition. That is,.a merger to monopoly requires the union of two (or more) independent units into one. Thus by approving it the state legislature expressed no opinion whatsoever on the creation of monopoly by merger, or for that matter any other merger that threatened to lessen competition.

\section{Conclusion}

Federal antitrust policy's commitment to federalism is strong - so strong, in fact, that it permits states to immunize almost any kind of intrastate conduct, provided that they state their wishes clearly and do not permit private actors to hijack the process. At the same time, however, the inference is strong that the states have a commitment to the maintenance of competition - attested by the fact that nearly every state has an antitrust law of its own, most of them modeled on the Sherman Act. For that reason the presumption must be strong that before state action immunity will be granted the state must assert with clarity that this was the policy it intended.

in 1963, further expanded the implicit power of the Board to acquire other hospitals. Thus, if the legislature knew at the time it expanded the Board's acquisition powers in 1987 that a monopoly had resulted from the 1963 legislation, the legislature must have reasonably anticipated that further acquisitions, resulting from the 1987 legislation, would increase the Board's market share in an anticompetitive manner. 